\title{
A global blended tropopause based on ERA data, Part I: Climatology
}

Article

Accepted Version

Wilcox, L., Hoskins, B. and Shine, K. (2012) A global blended tropopause based on ERA data, Part I: Climatology. Quarterly Journal of the Royal Meteorological Society, 138 (664). pp.

561-575. ISSN 1477-870X doi: https://doi.org/10.1002/qj.951 Available at https://centaur.reading.ac.uk/25077/

It is advisable to refer to the publisher's version if you intend to cite from the work. See Guidance on citing.

Published version at: http://onlinelibrary.wiley.com/doi/10.1002/qj.951/pdf

To link to this article DOI: http://dx.doi.org/10.1002/qj.951

Publisher: Royal Meteorological Society

All outputs in CentAUR are protected by Intellectual Property Rights law, including copyright law. Copyright and IPR is retained by the creators or other copyright holders. Terms and conditions for use of this material are defined in the End User Agreement.

\section{www.reading.ac.uk/centaur}

\section{CentAUR}

Central Archive at the University of Reading

Reading's research outputs online 


\title{
A global blended tropopause based on ERA data. Part I: Climatology
}

\author{
L. J. Wilcox, B. J. Hoskins, and K. P. Shine
}

\begin{abstract}
A new tropopause definition, based on a flow-dependent blending of the traditional thermal tropopause with one based on potential vorticity, has been developed. The benefits of such a blending algorithm are most apparent in regions with synoptic scale fluctuations between tropical and extratropical airmasses. The properties of the local airmass determine the relative contributions to the location of the blended tropopause, rather than this being determined by a specified function of latitude.

Global climatologies of tropopause height, temperature, potential temperature and zonal wind, based on European Centre for Medium-Range Weather Forecasts (ECMWF) reanalysis (ERA) ERA-Interim data, are presented for the period 1989-2007. Features of the seasonal-mean tropopause are discussed on a global scale, alongside a focus on selected monthly climatologies for the two high latitude regions and the tropical belt. The height differences between climatologies based on ERA-Interim and ERA40 data are also presented.

Key spatial and temporal features seen in earlier climatologies, based mainly on the World Meteorological Organization thermal tropopause definition, are reproduced with the new definition. Tropopause temperatures are consistent with those from earlier climatologies, despite some differences in height in the extratropics.
\end{abstract}

\section{Introduction}

As the troposphere and the stratosphere have many contrasting properties, it is possible to define the boundary between them, the tropopause, using several different diagnostics including the temperature lapse rate, potential vorticity and chemical concentrations.

Knowledge of the position of the tropopause is important for studies of mass exchange between the troposphere and stratosphere (e.g. Holton et al., 1995), and also for studies of the climate impact of aircraft, which fly close to the tropopause level. Additionally, column total ozone is dependent on tropopause height (e.g. Vaughan and Price, 1991), and the mixing ratio of stratospheric water vapour is dependent on the temperature of the tropical tropopause, across which air passes into the stratosphere (Randel et al., 2004). It has also been suggested by Santer et al. (2004) that the tropopause is a sensitive indicator 
of climate change, with trends in tropopause height being detectable over much shorter timescales than those in surface temperature.

Hoinka $(1998,1999)$ presented a global tropopause climatology, produced using the ERA-15 data set. Regional tropopause climatologies have also been produced by Highwood and Hoskins (1998), Highwood et al. (2000) and Zängl and Hoinka (2001), using both European Centre for Medium-Range Weather Forecasts (ECMWF) reanalyses (ERA) ERA-15 and radiosonde data. Hoinka (1998, 1999) and Zängl and Hoinka (2001) calculated climatologies for both a thermal and a dynamic tropopause definition. Highwood et al. (2000) considered only a thermal tropopause definition, while Highwood and Hoskins (1998) discussed the physical relevance of several tropopause definitions in the tropics. Hoinka $(1998,1999)$ also considered a latitude-dependent blending of a dynamic and thermal tropopause.

Global Positioning System (GPS) Radio Occultation (RO) data has made analysis of the global tropopause possible using high-resolution observational data. Early analysis of the thermal tropopause using this data has been presented by Schmidt et al. (2004) and Schmidt et al. (2005).

In this paper a new flow-dependent tropopause definition based on both thermal and potential vorticity definitions is presented in Section 3. Based on this definition, global tropopause climatologies have been produced using the ERA-40 and ERA-Interim data sets, as discussed in Section 4. The focus of the discussion is on results using the new tropopause definition in ERAInterim. A comparison between ERA-Interim and ERA-40 tropopause height is also included in Section 4.3. Trends in tropopause variables are presented in Part 2 (Wilcox et al., 2011).

\section{The ERA data sets}

Climatologies recording tropopause pressure and height above mean sea level, and potential temperature and horizontal wind components at the tropopause have been calculated using gridded data from ERA-40 and ERA-Interim. A reanalysis is an analysis using past observations calculated with a fixed data assimilation system, which makes them more consistent than operational analyses for the same period. ERA-40 covers the period from 1957 to 2002, and uses cycle 23R4 of the ECMWF Integrated Forecasting System (IFS). For an in-depth discussion of ERA-40, see Uppala et al. (2005). ERA-Interim covers the period from 1989 to the present day, and uses cycle 31R1 of the IFS (Dee et al., 2011). Here, ERA-Interim has been used for the period 1989-2007.

In ERA-40 the data analysis system used a grid with a horizontal resolution of T159 $\left(\sim 1.125^{\circ} \times 1.125^{\circ}\right)$ and 60 levels in the vertical up to $0.1 \mathrm{hPa}$. This data was interpolated by ECMWF from full model resolution onto a regular grid with 23 isobaric levels, and onto the $|\mathrm{PV}|=2$ PVU $\left(1 \mathrm{PVU}=1 \times 10^{6} \mathrm{~K} \mathrm{~m}^{2} \mathrm{~kg}^{-1}\right.$ $\mathrm{s}^{-1}$ ) potential vorticity (PV) surface. This is defined as $2 \mathrm{PVU}$ in the Northern Hemisphere, -2 PVU in the Southern Hemisphere, and, because of the vertical 
nature of these surfaces in the deep tropics, a cap at the position of the $380 \mathrm{~K}$ potential temperature surface is also used. The gridded ERA-Interim data used has a horizontal resolution of T255 $\left(\sim 0.703^{\circ} \times 0.703^{\circ}\right)$, and 37 isobaric levels, interpolated from 60 model levels. The isobaric levels in the gridded data sets are not evenly spaced, and a significant part of the increase in vertical resolution between ERA-40 and ERA-Interim is due to the inclusion of extra levels in the tropopause region.

In addition to the change in resolution, the different forecasting systems used to generate ERA-40 and ERA-Interim result in some key differences. Those likely to affect the tropopause surface are:

(i) The change from 3-D to 4-D Var (Andersson and Thépaut, 2008), which resulted in systematically better forecast performance, particularly in the Southern Hemisphere, where observations are often sparse.

(ii) Improvements in the treatment of humidity in ERA-Interim compared to ERA-40 significantly reduced the overestimation of precipitation discussed in Hagemann et al. (2005), particularly over the tropical oceans, with associated latent heating and circulation changes (Simmons et al., 2007).

(iii) Improvements in the representation of the stratosphere resulted in a more realistic age of air in the stratosphere in ERA-Interim, and also increased agreement with observations of stratospheric humidity and temperature. However, where the stratosphere in ERA-40 had a significant cold bias compared to other reanalyses, a positive bias is found in ERA-Interim (Simmons et al., 2007).

(iv) The use of bias correction in ERA-Interim when assimilating satellite radiance data removed many of the conflicting bias corrections found in ERA-40, improving the fit to "conventional data" (Simmons et al., 2007).

For the consideration of the Antarctic tropopause, it is also worth noting that vertical temperature profiles in the polar stratosphere from ERA-40 often contained a "spurious oscillatory structure" (Simmons et al., 2007). This structure is reduced in amplitude in ERA-Interim. For further discussions of the changes between ERA-40 and ERA-Interim see Simmons et al. (2007) and Dee et al. (2011).

\section{Tropopause definitions}

Three tropopause definitions will be discussed in this paper: a thermal, dynamic and blended definition.

\subsection{The thermal tropopause}

The thermal tropopause definition used here follows the WMO (1957) definition: the tropopause is "the lowest level at which the average lapse rate between 
this level and all higher levels within $2 \mathrm{~km}$ does not exceed $2^{\circ} \mathrm{C} \mathrm{km}{ }^{-1} "$. The tropopause is found from the gridded ERA data using the algorithm presented by Reichler et al. (2003), but with a high pressure bound of $500 \mathrm{hPa}$, following Gettelman and Baughcum (1999).

The thermal tropopause definition is used operationally and is common in previous work (e.g. Zängl and Hoinka (2001) and Highwood et al. (2000)). Its great advantage is that it can be determined from a single radiosonde ascent. However, there are known problems with its use. The thermal tropopause can be difficult to locate in the polar night regions, resulting in a discontinuous surface with a very high tropopause in some areas, and can be multi-valued in the vicinity of the polar jet (Figure 1). Importantly, it is not possible to characterise air masses using the thermal tropopause definition as the vertical temperature gradient is not a conservative quantity, even in the absence of diabatic processes.

Examples of some problems with the thermal tropopause determined from gridded data can be seen in Figure 1. Discontinuities are seen in the region of the subtropical jets. Such discontinuities are the result of the detection algorithm alternately identifying a high tropical tropopause and a low extratropical tropopause in the regions in which the tropopause is multi-valued.

Anomalous heights can be seen in the Antarctic region in both examples in Figure 1. The algorithm for identifying the thermal tropopause includes a low pressure bound of $75 \mathrm{hPa}$ (Reichler et al., 2003). This prevents some occurrences of an anomalously high-altitude tropopause, but is not sufficient in all cases. Some of the clearly anomalous heights identified in the polar night regions lie below the altitude of the tropical tropopause, so it is not possible to resolve this issue using a single pressure cap (e.g. Figure 1).

\subsection{The dynamic tropopause}

The dynamic tropopause is located at the position of a surface of constant potential vorticity. The use of PV means that in addition to considering the stability of the atmosphere, its circulation and density are also considered. As $\mathrm{PV}$ is materially conserved for adiabatic motion whereas lapse rate is not, it has been argued that a PV definition of the tropopause is more appropriate in regions of strong cyclonic activity (Zängl and Hoinka (2001)). The conservative properties of PV mean that a dynamic tropopause can be expected to evolve more smoothly, and in a more Lagrangian manner, than a thermal one, as seen in the observational studies of Danielsen (1968).

The dynamic tropopause is generally accepted to lie between $|\mathrm{PV}|$ values of 1 PVU and 4 PVU in the Northern Hemisphere (Hoskins et al., 1985, Kunz et al., 2011). Observational studies tend to place the surface at the lower end of this range (e.g. Danielsen $(1964,1968)$, observing radioactivity and ozone; Shapiro $(1978,1980)$, observing ozone and cloud condensation nuclei). Early studies based on Numerical Weather Prediction analyses, in which the dynamic tropopause is positioned at the PV value giving the best agreement with the thermal tropopause, have tended to define the dynamic tropopause using the 


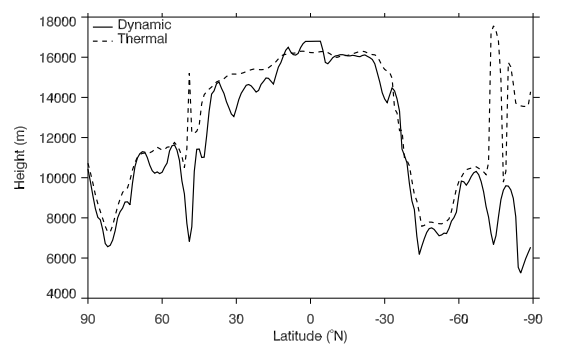

(a)

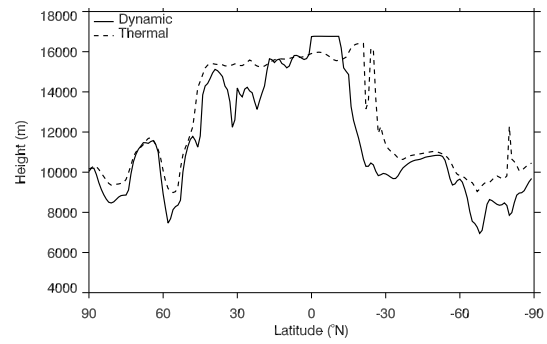

(b)

Figure 1: Latitudinal sections of the dynamic (solid line) and thermal (dashed line) tropopauses at $0^{\circ} \mathrm{W}$ for 6 hourly case studies: (a) 03 August 2002 at 00Z, (b) 11 August 2002 at $00 \mathrm{Z}$. 
higher values in this range (e.g. Hoerling et al. (1991), Zängl and Hoinka (2001)). However, Kunz et al. (2011) identified the dynamic tropopause at a range of values in the 1 to 4 PVU range using ECMWF operational analyses.

Following Hoskins et al. (1985), and Juckes (1994), the dynamic tropopause has been defined here as the position where $|\mathrm{PV}|=2 \mathrm{PVU}$. As discussed above, it is necessary to introduce a cap on the dynamic tropopause in the deep tropics. Here, as in the ERA data sets, this cap is put at $380 \mathrm{~K}$ potential temperature, which is often accepted as a good approximation for the tropical tropopause (e.g. Duncan et al., 2007). The resulting surface will herein be referred to as the "dynamic" tropopause. In the examples in Figure 1 the cap can be seen within a few degrees of the equator, slightly above the thermal tropopause there.

It can be seen in Figure 1 that the choice of $|\mathrm{PV}|=2$ PVU gives a reasonable agreement between the thermal and "dynamic" tropopause in the Northern Hemisphere and the tropics. The surfaces typically differ when there are depressions in the altitude of the "dynamic" tropopause associated with cyclonic activity. Such behaviour can be expected following e.g. Wirth (2000) and Wirth (2001), and is thought to be realistic.

Zängl and Hoinka (2001) argue that the use of relatively low values of PV to define a dynamic tropopause leads to over-detection of multiple tropopauses. When multiple surfaces where $|\mathrm{PV}|=2 \mathrm{PVU}$ are detected in the ERA analysis system, the algorithm uses the highest level.

The use of the ECMWF "dynamic" tropopause definition has the additional practical advantage that the ERA data has been directly interpolated from full vertical resolution model level data to this surface. This avoids the need to interpolate PV fields from data with a coarse vertical resolution, which would introduce errors.

\subsection{The blended tropopause}

Because of their respective advantages and disadvantages, a globally-valid flowdependent blending of the "dynamic" and thermal tropopauses has been developed. Previously, such definitions have been combined using a latitudedependent blending of the "dynamic" tropopause in the extratropics and the thermal tropopause in the tropics (e.g. Hoerling et al. (1991), Forster et al. (2003)). Although this avoids the key deficiencies associated with the component tropopauses, it is likely to misrepresent the airmass properties in the transition region. To avoid such an issue here, and enable a flow-dependent blending, the $350 \mathrm{~K}$ and $370 \mathrm{~K}$ isentropic surfaces have been used to define the boundaries of the transition region between the "dynamic" and thermal tropopauses (see Figure 2(a)). The height of the blended tropopause, $h_{b}$, has been defined as:

$$
h_{b}= \begin{cases}h_{d} & \theta_{d}<350 \mathrm{~K} \\ \left(\frac{\theta_{d}-350}{20}\right) h_{m}+\left(1-\frac{\theta_{d}-350}{20}\right) h_{d} & 350 \leq \theta_{d} \leq 370 \mathrm{~K} \\ h_{m} & \theta_{d}>370 \mathrm{~K}\end{cases}
$$

where $\theta_{d}$ is the potential temperature at the "dynamic" tropopause, $h_{m}$ is the lower of the height of the thermal tropopause $\left(h_{t}\right)$ and the height of the "dy- 
namic" tropopause $\left(h_{d}\right) . \quad h_{m}$ was used, instead of the height of the thermal tropopause, as the thermal tropopause can be difficult to identify from ERA data in the vicinity of the tropopause break, which can lead to an anomalously high and discontinuous surface (e.g. Figure 1 ). Using $h_{m}$, this behaviour is not passed on to the blended tropopause surface. This has the disadvantage that the $380 \mathrm{~K}$ cap on the "dynamic" tropopause is implicitly included in the definition. However, the cap is used in less than $10 \%$ of the 6 hourly tropopauses from 1989-2007, and generally only in small regions of the subtropics (Figure 2(b)). Comparisons between the thermal tropopause from ERA-40 and ERA-Interim revealed that the increased vertical resolution of ERA-Interim reduced the frequency of the identification of alternating high and low tropopauses in the subtropics. This result suggests that with higher resolution data sets it may be possible to replace $h_{m}$ with the height of the thermal tropopause, avoiding the use of the $380 \mathrm{~K}$ cap.

In the ERA-Interim climatology, the blended tropopause begins to depart from the "dynamic" tropopause equatorward of $\sim 45^{\circ} \mathrm{N}$, and $\sim 30^{\circ} \mathrm{S}$, when a degree of interpolation between $h_{d}$ and $h_{m}$ occurs (Figure 2(c)). However, because the blended definition takes account of the properties of local airmasses, the latitudes at which this occurs in a given 6 hour period can be very different. This can be seen in Figure 3 where tropical air can be seen extending into the extratropics, notably in the southern Indian Ocean in Figure 3(a) and in the North Atlantic in Figure 3(b), and is treated as such in the blended process. In a number of regions, the North and South Atlantic for example (Figure 3(a)), extratropical air penetrates into the subtropics. The flow-dependent blending algorithm used here can account for such features, whereas a simple latitudedependent algorithm would be unable to do so.

The frequency of the use of the blending algorithm (i.e. when $\theta \geq 350 \mathrm{~K}$ ) in the climatology can be seen in Figure 2(c). The frequency of the use of $h_{m}$ is shown in Figure $2(\mathrm{~d}) . h_{m}$ is typically used, to some degree, equatorward of $30^{\circ}$ latitude. The contributions to $h_{m}$ from the thermal and "dynamic" tropopauses are shown in Figures 2(e) and (f) respectively. The likelihood that $h_{m}=h_{t}$ increases with proximity to the equator, while $h_{d}$ is generally only used in the subtropics. When $h_{m}=h_{t}$, the height of the "dynamic" tropopause is equal to the height of the $380 \mathrm{~K}$ cap in less than $10 \%$ of all 6 hour periods from 1989-2007 (Figure 2(b)).

In the extratropics, the "dynamic" tropopause is always used in the blended tropopause, and is typically 500 to $1000 \mathrm{~m}$ lower than the thermal tropopause as a result of averaging the type of differences seen in Figure 1. The difference between the thermal and "dynamic" tropopause is largest near the South Pole in the zonal-mean (Figure 2(a)). This is due to the inclusion in the mean of the anomalously high thermal tropopause that is often identified using the thermal definition in the polar night. Equatorward of $10^{\circ}$ latitude the $380 \mathrm{~K}$ cap on the "dynamic" tropopause makes it on average $100 \mathrm{~m}$ higher than the thermal and blended tropopauses. The blended tropopause definition is a small but significant modification to the "dynamic" tropopause, as the difference between the surfaces in the tropics can be considerably larger at a given time and location 

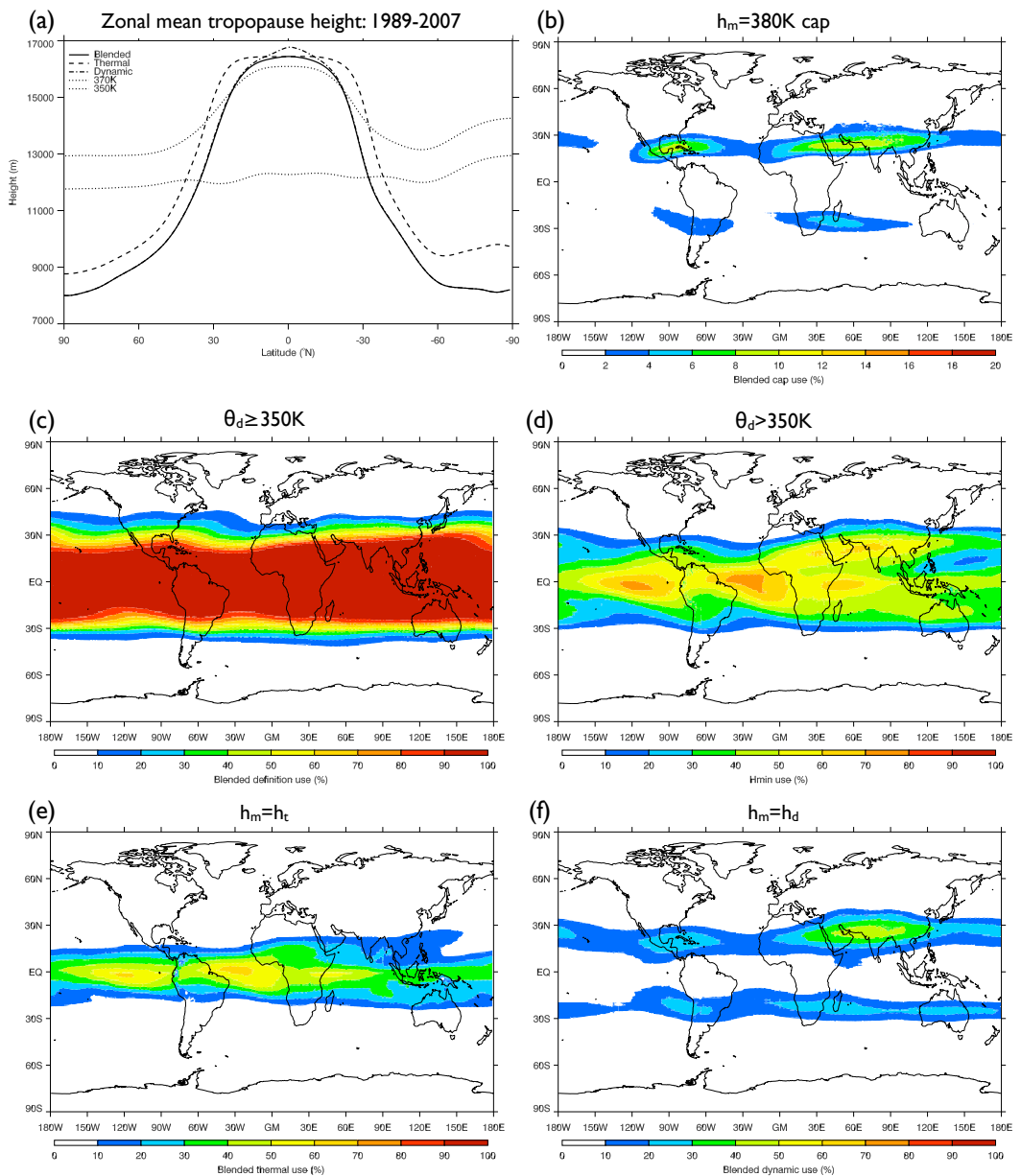

Figure 2: (a): Zonal-mean annual-mean tropopause height from the ERAInterim climatology using the blended (solid line), thermal (dashed line) and "dynamic" (dash-dotted line) tropopause definitions. The position of the zonalmean annual-mean 350 and $370 \mathrm{~K}$ potential temperature surfaces are indicated by the dotted lines. (b): the percentage of 6 hourly blended tropopauses with height equal to the height of the $380 \mathrm{~K}$ cap, (c): percentage with $\theta_{d}$ greater than or equal to $350 \mathrm{~K}$, (d): percentage with $\theta_{d}$ greater than $370 \mathrm{~K}$, (e): percentage where $h_{m}$ is equal to the height of the thermal tropopause, and (f): percentage where $h_{m}$ equal to the height of the "dynamic" tropopause. 


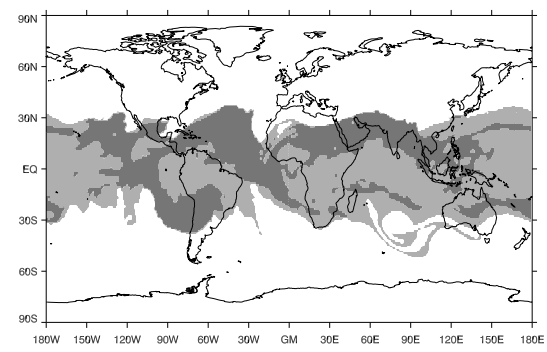

(a)

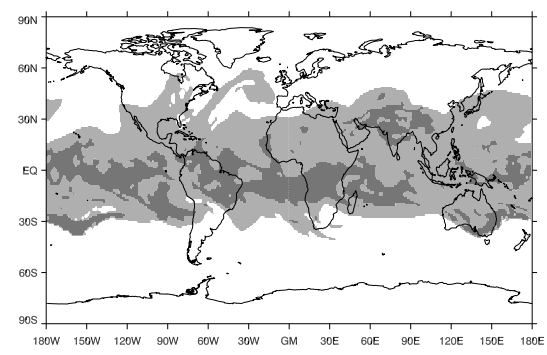

(b)

Figure 3: The composition of the blended tropopause: 6 hour case studies. White space indicates the region where the "dynamic" tropopause is used, light shading indicates the interpolation region between $350 \mathrm{~K}$ and $370 \mathrm{~K}$, and dark shading indicates where $h_{m}$ is used. (a): 10 January 2002, 00Z, (b): 10 August 2002, 00Z. 
than in the climatological zonal mean (differences of up to $2 \mathrm{~km}$ can be seen in Figure 1).

The height difference between the thermal and "dynamic" tropopause is reflected in the comparison between the blended tropopause and those from previous studies, where it is typical for the thermal tropopause, or a value of PV that places the mean dynamic tropopause close to it, to be used. In particular, the blended tropopause has a lower altitude at the poles compared to previous work (e.g. Hoinka, 1998; Highwood et al., 2000). In the tropics the altitude of the blended tropopause is generally in good agreement with previously reported values from studies where the thermal tropopause is used (e.g. Seidel et al., 2001; Schmidt et al., 2004).

\section{Tropopause climatology}

In addition to 6 hourly, monthly, extended winter (December to March: DJFM) and summer (June to August: JJA) tropopause data for each year, monthly and seasonal climatologies for the years 1989-2007 have been produced using both ERA-40 and ERA-Interim. The four month northern winter is used to include all months with an active Northern Hemisphere polar vortex. The climatology contains "dynamic", thermal and blended tropopause height above mean sea level, and blended tropopause pressure, potential temperature, and the zonal and meridional components of horizontal wind at the tropopause. It should be noted that the wind field at the tropopause has the special property that it includes the maxima in both the subtropical and polar jets.

In the following sections the key features of the blended tropopause climatologies for DJFM and JJA using ERA-Interim will be discussed. In Section 4.4 regional features are discussed in more detail.

\subsection{DJFM}

In DJFM, tropopause height has minima at the two poles, and a maximum in the tropics (Figure 4(a)). The Northern Hemisphere (NH) polar minimum extends over north eastern Canada and Siberia, in agreement with many previous studies e.g. Hoinka (1998) and Schmidt et al. (2005). The higher subtropical tropopause extends north east towards the northeast Atlantic and up the west coast of North America. There are large gradients in height in the subtropics, which are strongest in the winter hemisphere. Slightly equatorward of these are strong gradients in temperature (Figure 4(b)), as expected from their location on the jet stream axis, and as observed by Hoinka (1999). The poleward shift of the tropopause height contours over the North Atlantic and North Pacific reflect the paths of the jet streams, which are indicated by the maxima in zonal wind in Figure 4(d). Both the subtropical and mid-latitude jets are well depicted on this surface. In particular, the closed loop around the Southern Hemisphere $(\mathrm{SH})$, and spiral in the $\mathrm{NH}$ are apparent. 
(a)

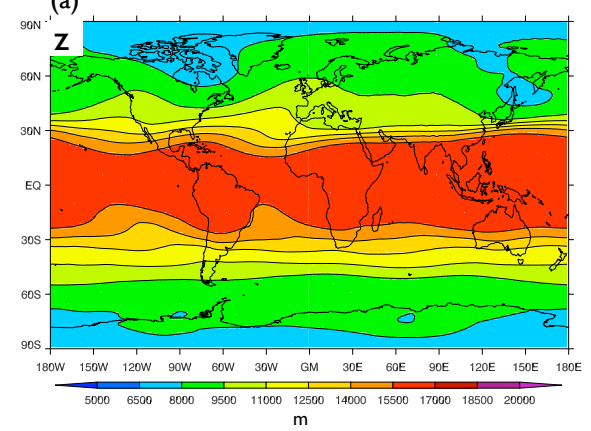

(c)

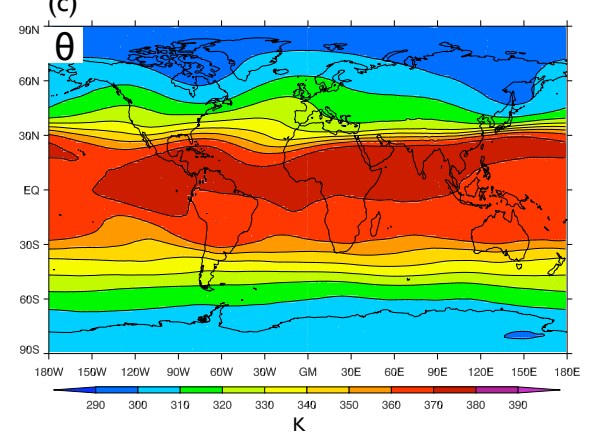

(b)
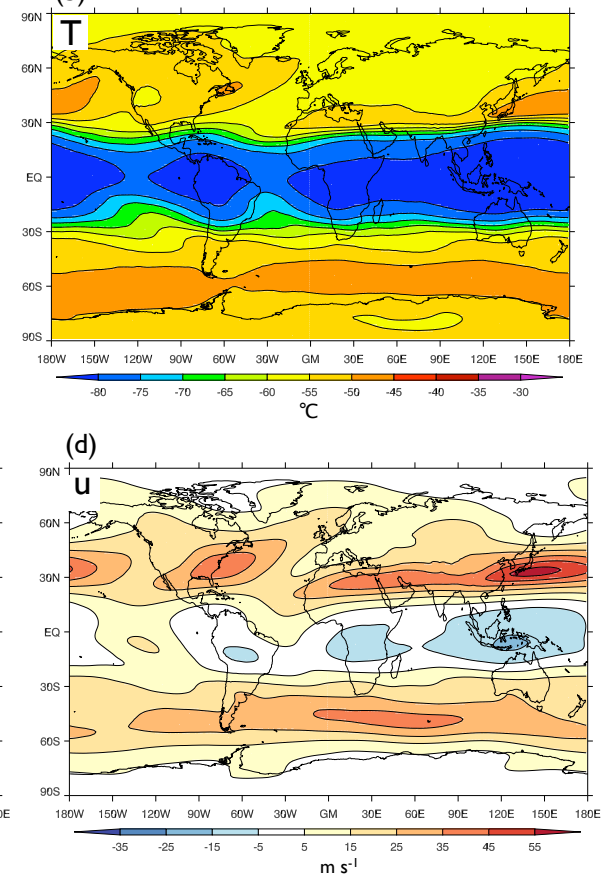

Figure 4: DJFM climatologies at the blended tropopause from ERA-Interim (1989-2007) (a): tropopause height $(\mathrm{m})(\mathrm{b})$ : tropopause temperature $\left({ }^{\circ} \mathrm{C}\right)(\mathrm{c})$ : tropopause potential temperature $(\mathrm{K})(\mathrm{d})$ : tropopause level zonal wind $\left(\mathrm{m} \mathrm{s}^{-1}\right)$

The strongest westerly winds $\left(\leq 59 \mathrm{~m} \mathrm{~s}^{-1}\right)$ are found in the NH over Japan and over the western half of the North Pacific. There are easterlies over much of the tropics, which have a maximum over the warm pool in the equatorial Pacific. The winds over the equatorial east Pacific are westerly in DJFM.

In DJFM, the minimum tropopause temperature of $-86^{\circ} \mathrm{C}$ occurs over Indonesia (Figure 4(b)), in the same location as the height maximum of $16800 \mathrm{~m}$. The temperature maxima in the subtropics correspond to the position of the poleward edge of the jet maxima (Figure 4(d)). There are secondary temperature minima over Siberia and Antarctica.

Potential temperature has a maximum of just less than $380 \mathrm{~K}$ on the northern side of the Equator, and a minimum of $290 \mathrm{~K}$ over the Northern Hemisphere high latitudes (Figure 4(c)). Large gradients in potential temperature are collocated with the large height and temperature gradients, and zonal wind maximum, over Japan. Globally, contours of potential temperature closely follow contours of height.

Zonal-mean sections from the ERA-Interim climatology are shown in Figure 5. In DJFM, zonal-mean tropopause height is $\sim 8000 \mathrm{~m}$ at the poles (Fig- 
ure $5(\mathrm{a})$ ). In the $\mathrm{NH}$, tropopause height increases gradually with distance from the poles in the extratropics, before increasing rapidly near $30^{\circ}$ latitude (Figure $5(\mathrm{a})$ ). In the $\mathrm{SH}$ there is a more pronounced transition near $60^{\circ}$ latitude. The tropopause height is of the order $16500 \mathrm{~m}$ in the tropics, with a maximum near the Equator.

The maxima in the zonal-mean six-hourly standard deviation of tropopause height $(2000 \mathrm{~m}$ for the $\mathrm{NH}$ and $1750 \mathrm{~m}$ for the $\mathrm{SH}$ ) are associated with variability of the steep subtropical transition between the tropical and mid-latitude tropopause heights (Figure 5(a)). There are also relatively large standard deviations in tropopause height associated with the polar jets at $50-60^{\circ}$ latitude. Standard deviation is larger in the SH extratropics, but it is smaller over the southern pole. The standard deviation of tropopause height has a deep minimum in the equatorial region (Figure 5(a)). The latitudes of the maxima in standard deviation, and the broader peak in the $\mathrm{SH}$ compared to the $\mathrm{NH}$, are in agreement with the pattern of standard deviation in tropopause pressure presented by Schmidt et al. (2005).

Tropopause pressure (Figure 5(c)) mirrors height, ranging from $335 \mathrm{hPa}$ at the poles to $100 \mathrm{hPa}$ at the Equator. As expected from the choice of the critical $\mathrm{PV}$ value in the "dynamic" tropopause definition, pressure at the poles is high in comparison to previous work (e.g. $50 \mathrm{hPa}$ higher than the thermal tropopause values reported by Schmidt et al. (2005)).

Potential temperature (Figure $5(\mathrm{c})$ ) has a similar structure to height, with zonal-mean values close to $300 \mathrm{~K}$ at the poles, and a maximum of $370 \mathrm{~K}$ in the tropics. Asymmetry in tropical potential temperature, with larger values in the $\mathrm{NH}$, is more pronounced than that in pressure and height. The potential temperature of the blended tropopause at the poles is comparable to the values found by Hoinka (1999), and in the tropics is comparable to the thermal tropopause values reported by Seidel et al. (2001).

The DJFM zonal-mean tropopause temperature has a minimum $\left(-82^{\circ} \mathrm{C}\right)$ in the region of the high equatorial tropopause (Figure 5(e)), corresponding to the location of the height maximum. Tropopause temperature increases rapidly away from the equator, and in the $\mathrm{NH}$ reaches a maximum of $-55^{\circ} \mathrm{C}$ at $30^{\circ} \mathrm{N}$, coincident with the maximum in zonal wind (Figure 5(e)). In the $\mathrm{SH}$, the temperature is generally warmer than that in the $\mathrm{NH}$, and the temperature maximum $\left(-48^{\circ} \mathrm{C}\right)$ occurs some $10^{\circ}$ poleward of the wind maximum.

The temperature range and latitudinal distribution in the $\mathrm{NH}$ and tropics is in very good agreement with the temperatures found by Schmidt et al. (2005) and Hoinka (1999), despite the differences in height, and in good agreement with the results of Schmidt et al. (2005) in the SH. Blended tropopause temperature in the SH high latitudes are warm compared to those shown by Hoinka (1999).

The tropopause level zonal wind has a minimum of $-3 \mathrm{~m} \mathrm{~s}^{-1}$ in the tropics on the summer side of the Equator (Figure 5(e)), and maxima of $35 \mathrm{~m} \mathrm{~s}^{-1}$ at $30^{\circ} \mathrm{N}$ and $30 \mathrm{~m} \mathrm{~s}^{-1}$ at $45^{\circ} \mathrm{S}$. 


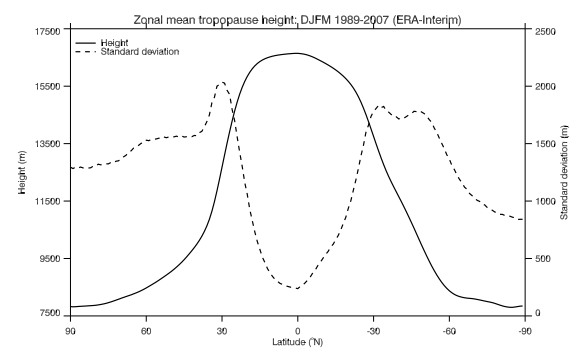

(a)

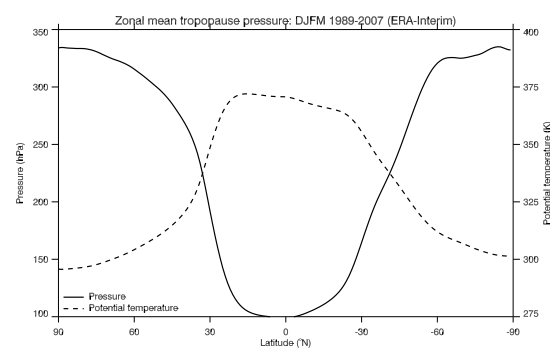

(c)

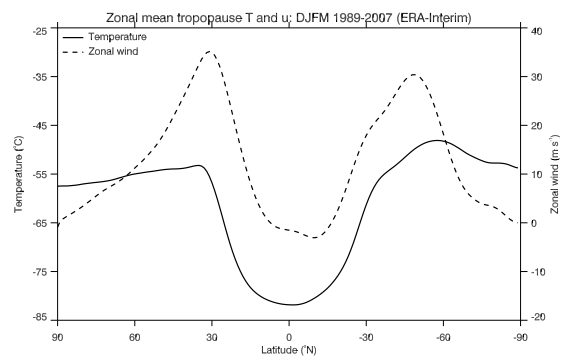

(e)

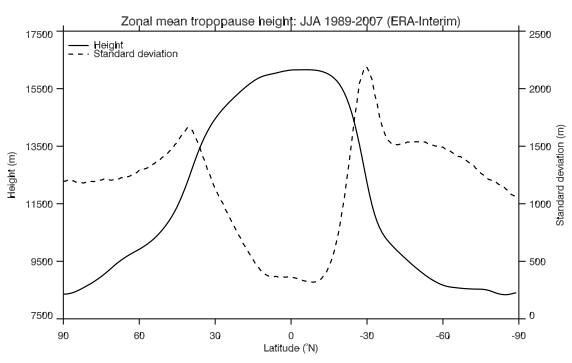

(b)

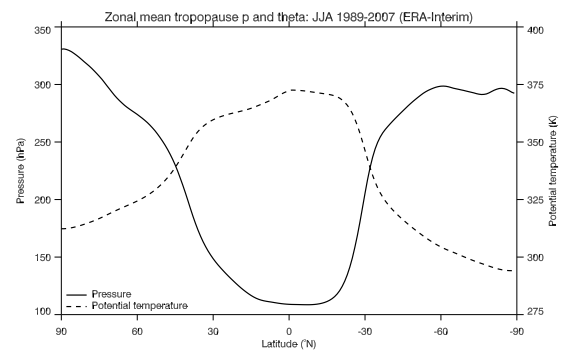

(d)

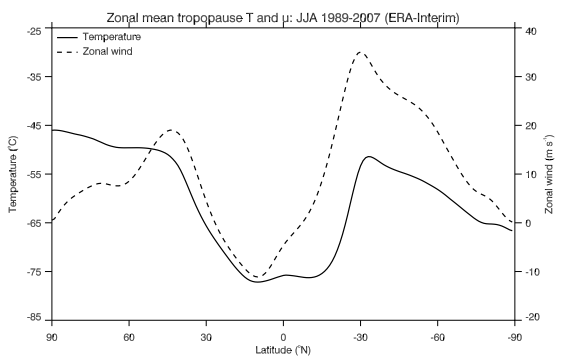

(f)

Figure 5: Zonal-mean sections for the ERA-Interim seasonal climatologies (19892007). Blended tropopause height $(\mathrm{m})$ and standard deviation of height $(\mathrm{m})$ for DJFM (a) and JJA (b), tropopause pressure $(\mathrm{hPa})$ and potential temperature $(\mathrm{K})$ for DJFM (c) and JJA (d), and tropopause temperature $\left({ }^{\circ} \mathrm{C}\right)$ and zonalmean tropopause-level zonal wind $\left(\mathrm{m} \mathrm{s}^{-1}\right)$ for DJFM (c) and JJA (d). 
(a)
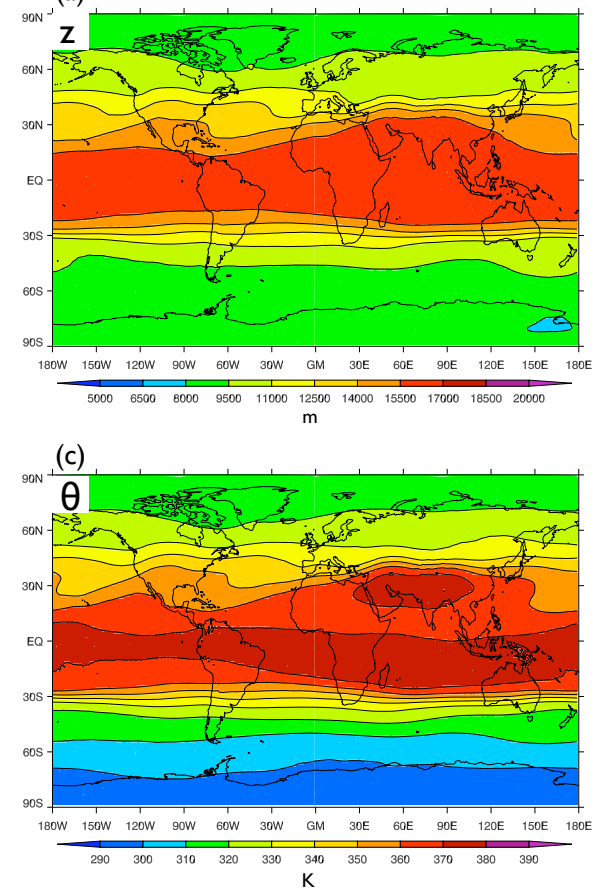

(b)
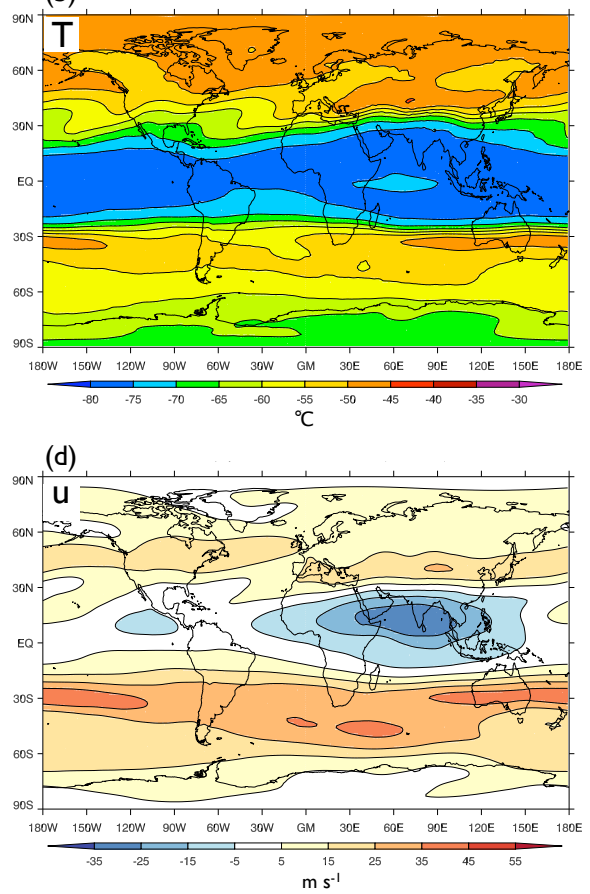

Figure 6: JJA climatologies at the blended tropopause from ERA-Interim (19892007). (a): Tropopause height $(m)$ (b): Tropopause temperature $\left({ }^{\circ} C\right)(c)$ : Tropopause potential temperature $(K)(d)$ : Tropopause level zonal wind $\left(\mathrm{m} \mathrm{s}^{-1}\right)$.

\section{$4.2 \quad$ JJA}

In JJA the global tropopause is generally higher than in DJFM (cf. Figure 6(a) and Figure 4(a)). The main tropical feature in all fields is associated with the Asian summer monsoon, and in particular the upper tropospheric anticyclone associated with it. In height the maximum is centred over the Indian Ocean and extends to the west Pacific, and across Africa (see Figure 6(a)). There is a poleward extension of the otherwise zonal structure over the Arabian peninsula, India and south-east Asia.

The NH jet is weaker in JJA than in DJFM, nowhere exceeding $30 \mathrm{~m} \mathrm{~s}^{-1}$, and more zonally symmetric (compare Figures 6(d) and 4(d), and Figures 5(c) and (d)). In JJA the $\mathrm{SH}$ jet is stronger, and less zonally symmetric than in DJFM, with maximum zonal wind speeds in excess of $45 \mathrm{~m} \mathrm{~s}^{-1}$ over the South Pacific. The $\mathrm{SH}$ jet is split near $75^{\circ} \mathrm{E}$. There are considerable differences in zonal wind in the tropics between DJFM and JJA. In JJA there are strong easterlies associated with the Asian monsoon over the northern Indian Ocean, and India, which are on the equatorward side of the height maximum (Figure 6(d)). There 
are also easterly winds over the eastern Pacific, in contrast to the westerlies found in DJFM.

Globally, like height, tropopause temperature is more zonally uniform in JJA compared to DJFM (cf. Figures 6(c) and 4(c)). The Arctic and extratropical tropopause in JJA is warmer (typically $-55^{\circ}$ to $-60^{\circ} \mathrm{C}$ ) compared to the Antarctic tropopause in DJFM, and the Antarctic tropopause in JJA is much colder than the DJFM Arctic tropopause. The tropical tropopause is warmer in JJA compared to DJFM. The tropical temperature minimum $\left(\geq-79^{\circ} \mathrm{C}\right)$ extends around the globe between $\pm 15^{\circ}$ latitude, with the minimum extending over the Asian subcontinent, like the height field. In the NH extratropics, temperatures are still more zonally uniform than in DJFM, but they are generally warmer in the eastern hemisphere. Temperature maxima of up to $-45^{\circ} \mathrm{C}$ are found over the $\mathrm{NH}$ high latitudes, and over Asia at $40^{\circ} \mathrm{N}$. The temperature maxima at $40^{\circ} \mathrm{N}$ are located slightly to the west of maxima in zonal wind (Figure 6(b)).

The potential temperature maximum lies over the Asian subcontinent in JJA (Figure 6(c)), and is associated with the monsoon anticyclone. There is also a zonal band of high potential temperature values in the tropics, situated mostly to the south of the Equator. Potential temperature in the JJA SH high latitudes is comparable to that in the DJFM NH high latitudes. Potential temperature is larger in the JJA NH high latitudes compared to the DJFM SH high latitudes.

Zonal means of JJA variables are shown in panels b, d, and $\mathrm{f}$ of Figure 5. Tropopause height (Figure 5(b)) is higher in the extratropics and high latitudes in both hemispheres in JJA compared to DJFM, as was seen when comparing Figures 6(a) and 4(a). Height gradients in the SH in JJA are comparable to those in the NH in DJFM, while gradients in the NH in JJA are shallower than those in the SH in DJFM. The standard deviation of tropopause height (Figure 5(b)) has a sharp maximum of $2200 \mathrm{~m}$ in the $\mathrm{SH}$ near $30^{\circ} \mathrm{S}$ in JJA, in the same location as the maximum $\left(35 \mathrm{~m} \mathrm{~s}^{-1}\right)$ in zonal wind, but slightly equatorward of that identified by Schmidt et al. (2005). The double peaked standard deviation seen in the SH in DJFM, associated with a split jet, is not present in JJA. In the NH, the maximum standard deviation is shifted slightly poleward compared to DJFM, and is reduced in amplitude.

Tropopause pressure again mirrors tropopause height (c.f. Figure 5(b) and Figure 5(d)). Pressure is higher in the tropics in JJA compared to DJFM. Tropopause pressure is comparable in the DJFM SH high latitudes to that in the JJA NH high latitudes. However, in JJA, NH pressure steadily increases with decreasing latitude, while in the DJFM SH it is nearly constant from 90 $-60^{\circ} \mathrm{S}$. The pressure near the South Pole in JJA is less than that near the North Pole in DJFM, with steeper pressure gradients in the subtropics. In JJA the potential temperature maximum is on the south side of the Equator (Figure 5(d)). Potential temperature is higher in the JJA NH compared to the DJFM SH, while potential temperatures are comparable in the JJA SH and the DJFM NH (Figure 5(c) and (d)).

Zonal-mean zonal wind and temperature are shown in Figure 5(f). Temperature has a similar, but reversed, latitudinal structure to that seen in the DJFM mean. The latitudinal gradient in SH high latitudes is steeper than the equiva- 


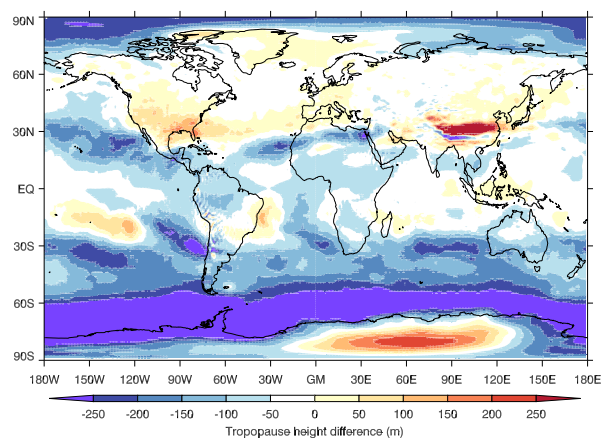

(a)

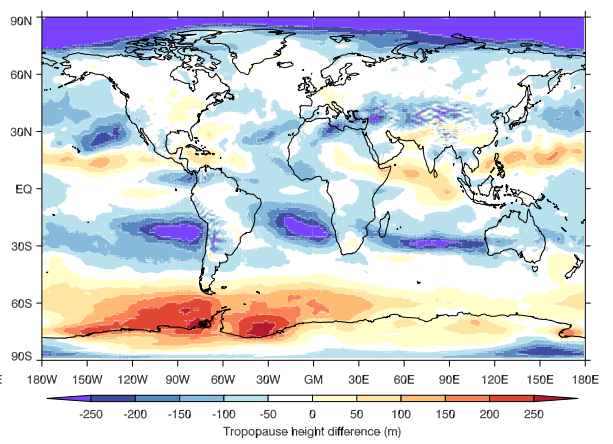

(b)

Figure 7: Difference (ERA-40 - ERA-Interim) between the DJFM (a) and JJA (b) seasonal climatologies (1989-2002) of blended tropopause height (m).

lent in the NH in DJFM. Tropical tropopause temperature is about $5^{\circ} \mathrm{C}$ warmer in JJA $\left(-77^{\circ} \mathrm{C}\right.$ compared to $\left.-82^{\circ} \mathrm{C}\right)$. Temperature, and its latitudinal structure, is in good agreement with the observed thermal tropopause presented by Schmidt et al. (2005).

The zonal wind maximum $\left(35 \mathrm{~m} \mathrm{~s}^{-1}\right)$ is located near $30^{\circ} \mathrm{S}$, and there is a greater difference between the $\mathrm{SH}$ and $\mathrm{NH}$ maxima compared to DJFM (c.f. Figure 5(f) and Figure 5(e)). Zonal-mean easterlies are stronger in JJA than in DJFM $\left(-11 \mathrm{~m} \mathrm{~s}^{-1}\right.$ compared to $\left.-3 \mathrm{~m} \mathrm{~s}^{-1}\right)$.

\subsection{The difference between ERA-40 and ERA-Interim}

The ERA-Interim and ERA-40 blended tropopause climatologies have been compared for the period January 1989-August 2002, where they overlap. The height differences (ERA-40 minus ERA-Interim) in DFJM and JJA are shown in Figure 7.

Globally, there are only relatively small differences between the ERA-40 and ERA-Interim tropopause heights. The two surfaces are generally within $300 \mathrm{~m}$ of each other, which is less than the difference between the thermal and "dynamic" tropopauses in the zonal mean (Figure 2(a)), and most ERA pressure levels. The only difference exceeding $500 \mathrm{~m}$ between the two climatologies in DJFM is in the lee of the Himalayas. Here, the ERA-40 tropopause is locally up to $2 \mathrm{~km}$ higher than the ERA-Interim tropopause. The ERA-40 tropopause level westerlies here are also weaker than those from ERA-Interim, and the temperatures are cooler. The differences in this region are most pronounced in DJFM, and appear to be associated with large vertical, and, to a lesser extent, horizontal oscillations in the ERA-40 potential vorticity, potential temperature and zonal wind fields (not shown). The origins of these oscillations are unknown. It is suspected that they may be the result of the parameterisation of gravity 
wave drag in ERA-40.

In addition to the very large differences in the lee of the Himalayas, there are smaller differences between the tropopause heights from the two climatologies. The most notable of these are in the SH high latitudes. Here, the (DJFM) ERAInterim tropopause is over $250 \mathrm{~m}$ higher than the ERA-40 tropopause around the Antarctic coast, but lower over the continent itself. This is probably the result of the change from 3-D to 4-D Var between ERA-40 and ERA-Interim, which is known to have had a large impact on the SH (Andersson and Thépaut, 2008).

There are also differences in height of up to $100 \mathrm{~m}$ in the tropics. It is possible that this is due to the improved treatment of humidity in ERA-Interim, and the subsequent impacts on convection and latent heating. Differences between tropopause heights from the two climatologies are smaller in the $\mathrm{NH}$, where there is more observational coverage and the data is less sensitive to changes in the forecasting system.

Tropopause heights from ERA-40 and ERA-Interim are always within 500 $\mathrm{m}$ of each other in JJA. Differences in height in the tropics are slightly larger in JJA compared to DJFM, but the tropopause heights from the two climatologies are within $200 \mathrm{~m}$ of each other there. The largest differences in the tropics are over the South Pacific and South Atlantic, where the ERA-Interim tropopause is higher, and over the Indian Ocean and the West Pacific, where ERA-40 is higher.

There are large differences between the surfaces in the SH high latitudes, but with a different structure than found in DJFM. In JJA the ERA-40 tropopause is generally higher (by up to $250 \mathrm{~m}$ ) than the ERA-Interim tropopause over the whole region. However, it should be noted that the tropopause is not necessarily well defined in the SH high latitudes in JJA.

Tropopause temperature (not shown) is generally lower in the ERA-Interim climatology compared to the ERA-40 climatology in the the tropics and Arctic in both seasons. The ERA-40 tropopause is warmer by $1-2^{\circ} \mathrm{C}$ in the Arctic. In the tropics the difference can be as much as $6^{\circ} \mathrm{C}$, with a maximum temperature difference over the central Pacific in JJA. The temperature difference over the Antarctic can be as large as $5^{\circ} \mathrm{C}$, and changes sign throughout the year, having the opposite sign to the height difference.

Tropopause-level zonal winds (not shown) are generally within $2 \mathrm{~m} \mathrm{~s}^{-1}$ in the two climatologies. However, in JJA the westerly winds over the southern Indian Ocean are up to $6 \mathrm{~m} \mathrm{~s}^{-1}$ weaker in ERA-40 compared to ERA-Interim. There are also large differences in the lee of the Himalayas in DJFM, in the same location as the very large height differences.

\subsection{Regional Analysis}

A global analysis of the tropopause encompasses a large range of features determined by a range of physical mechanisms. Therefore, it is useful for discussion to divide the globe into a number of regions. In this section the tropopause 
in the $\mathrm{NH}$ and $\mathrm{SH}$ high latitude regions, and the tropics, will be considered separately.

\subsubsection{The northern high latitudes}

Monthly climatologies of the height and temperature of the ERA-Interim blended tropopause poleward of $40^{\circ} \mathrm{N}$ are shown at two-monthly intervals in Figure 8. Throughout the year there is a minimum in height over or near the pole. From April to September, the height minimum is centred over the pole, being at its weakest in July. In November the minimum elongates, having a primary minimum over north east Canada, and a secondary minimum between $130^{\circ} \mathrm{E}$ and $140^{\circ} \mathrm{E}$ at $55^{\circ} \mathrm{N}$. Although there are small differences in the exact location of the minima, both Highwood et al. (2000) and Zängl and Hoinka (2001) identified a similar pattern of a primary and secondary minimum on the eastern side of the continents.

Temperature is less zonally uniform compared to height, especially from October to April when the eastern hemisphere is relatively cold compared to the western hemisphere (Figure 8). Highwood et al. (2000) found a similar asymmetry between the western and eastern hemispheres in DJFM.

There is a temperature minimum over Asia, about $30^{\circ} \mathrm{W}$ of the height minimum, present from November until May. Zängl and Hoinka (2001) also identified a temperature minimum over Eurasia, but located to the west of the secondary minimum shown in Figure 8. The storm track regions are warm compared to their surroundings throughout the year, with the temperature maxima located on the poleward side of the zonal wind maxima. There are also relatively warm temperatures over the pole from May to September.

There are large annual cycles in all tropopause parameters at high latitudes. Arctic tropopause height (the average poleward of $65^{\circ} \mathrm{N}$ ) has a minimum of $7800 \mathrm{~m}$ in March, and a maximum of $9000 \mathrm{~m}$ in July. This differs slightly from Highwood et al. (2000), who found a maximum in Arctic tropopause pressure in April and a minimum in August. However, when the annual cycle of the thermal tropopause, as used by Highwood et al., is considered, the results are in agreement. Arctic temperature has a minimum $\left(-58^{\circ} \mathrm{C}\right)$ in January and a maximum $\left(-47^{\circ} \mathrm{C}\right)$ in July.

Zängl and Hoinka (2001) identified a 'double wave' pattern in the seasonal variation of Arctic tropopause pressure, with pressure maxima in summer and winter for most of the Arctic. There is some suggestion of this pattern in the cycle for the Arctic north of $65^{\circ} \mathrm{N}$ in the blended tropopause climatology (not shown), but it is very weak. The summer height maximum is much larger than the secondary one found in winter, meaning that there is little to distinguish this pattern from the other regional cycles. For regions closer to the pole the double wave identified by Zängl and Hoinka (2001) becomes more apparent. 

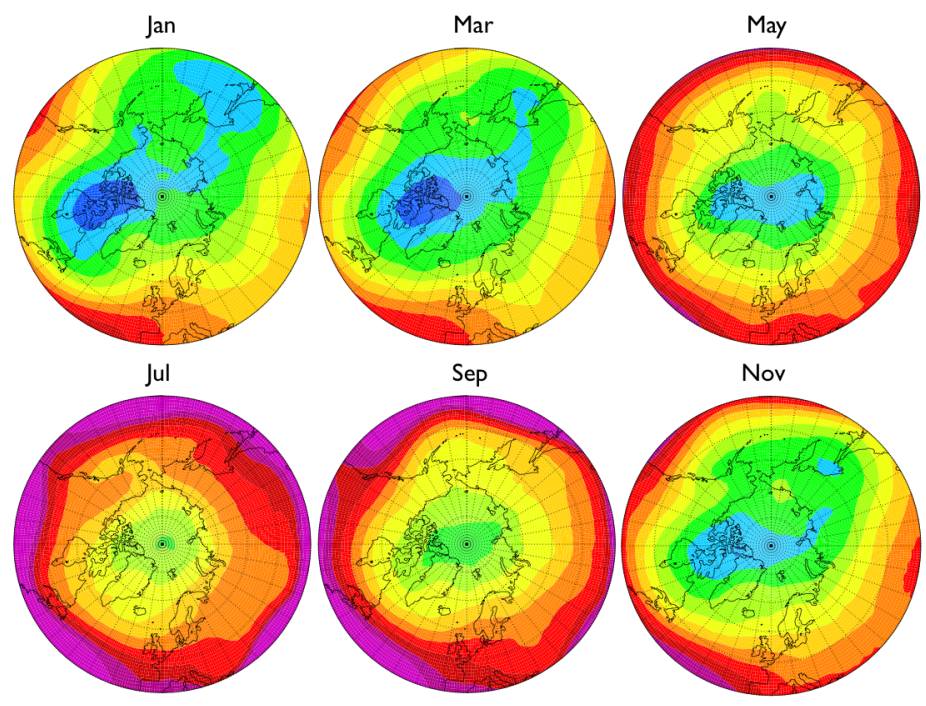

7000750080008500900095001000010500110001150012000 Tropopause height $(\mathrm{m})$
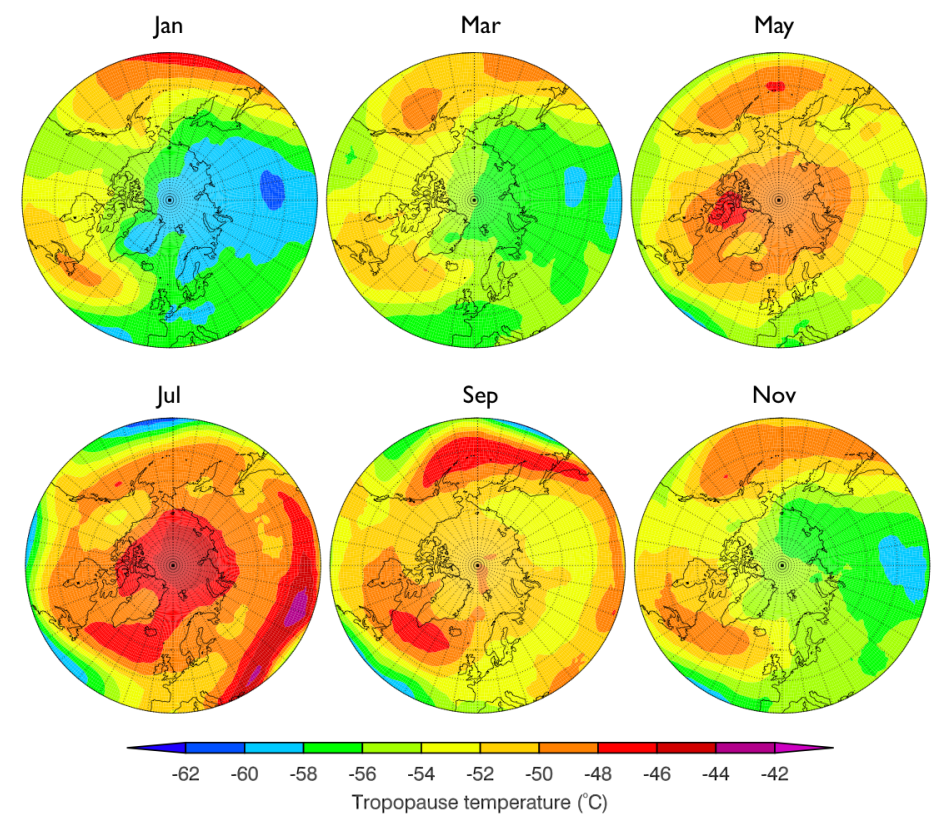

Figure 8: Monthly climatologies of blended tropopause height (m) (top) and temperature $\left({ }^{\circ} \mathrm{C}\right)$ (bottom) from the ERA-Interim climatology (1989-2007) in the NH high latitudes $\left(40-90^{\circ} \mathrm{N}\right)$ in January, March, May, July, September and November. 


\subsubsection{The southern high latitudes}

It is well established that the thermal tropopause is difficult to locate in SH high latitudes, particularly in the polar night (e.g. Highwood et al., 2000), because of the gradual transition from a tropospheric to a stratospheric lapse rate profile. Although it is always possible to identify a position where $\mathrm{PV}=-2 \mathrm{PVU}$, the significance of the "dynamic" tropopause definition in Antarctic winter also has to be questioned as the transition from tropospheric to stratospheric potential vorticity can also be gradual. As such, tropopause parameters in the Antarctic region in Austral winter should be approached with a degree of caution.

For completeness, selected monthly climatologies of the height and temperature of the ERA-Interim blended tropopause poleward of $40^{\circ} \mathrm{S}$ are shown in Figure 9. The minimum in tropopause height is never centred over the pole, unlike the $\mathrm{NH}$ where the minimum is only away from the pole from December to March. Height is generally lower in SH autumn, in contrast to the NH where the lowest tropopause heights occur in the winter (Figure 8). The Antarctic is the only region considered that does not have a tropopause height minimum in winter. From June to November zonal asymmetries in tropopause height are marked, with lower heights in the eastern hemisphere, forming a crescent off the Antarctic coast. From July to September the minimum is centred near $90^{\circ} \mathrm{E}$. It moves over the Greenwich meridian in October to December, before fragmenting in January, and moving over the continent during the succeeding months.

There is a minimum in tropopause temperature located over or near the pole throughout the year (Figure 9). From June to October the minimum covers a large area, is quite circular, and centred on the pole. This is in contrast to its reduced extent and more asymmetrical appearance in other months. From October to June there is a region of high tropopause temperature around the Antarctic continent, centred on $55^{\circ} \mathrm{S}$.

Antarctic tropopause height (the average poleward of $65^{\circ} \mathrm{S}$ ) has a minimum of $7700 \mathrm{~m}$ in March, and a maximum in September of $8600 \mathrm{~m}$. Antarctic temperature and pressure both have a minimum in August and a maximum in February. Although the amplitude and magnitude of the annual cycle in tropopause height in the Arctic and Antarctic are similar, the Antarctic tropopause is colder. Temperatures range from $-66^{\circ} \mathrm{C}$ to $-51^{\circ} \mathrm{C}$, compared to $-58^{\circ} \mathrm{C}$ to $-46^{\circ} \mathrm{C}$ in the Arctic. Such a difference in temperature is consistent with Hoinka (1999).

\subsubsection{The tropics}

Climatologies of monthly mean tropical tropopause temperature are shown in Figure 10. These are shown every month for the Asian monsoon season, and bi-monthly for the rest of the year. From November to April the changes in the structure of tropopause temperature are small. The temperature minimum is located, along with the height maximum (not shown), over the west Pacific. There are secondary temperature minima over the west coast of South America, and over equatorial Africa. A similar spatial structure was identified in the thermal tropopause from GPS RO observations by Schmidt et al. (2004). 

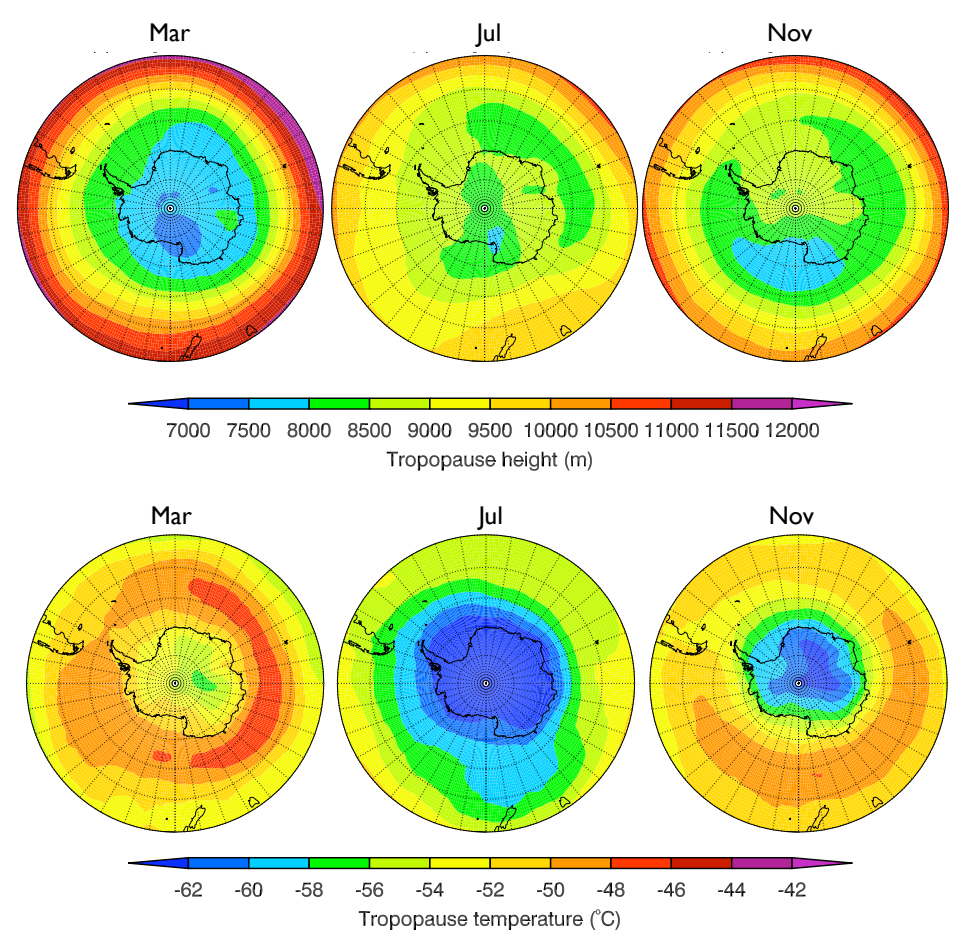

Figure 9: Monthly climatologies of blended tropopause height (m) (top) and temperature $\left({ }^{\circ} \mathrm{C}\right)$ (bottom) from the ERA-Interim climatology (1989-2007) in the SH high latitudes $\left(40-90^{\circ} \mathrm{S}\right)$ in March, July and November. 

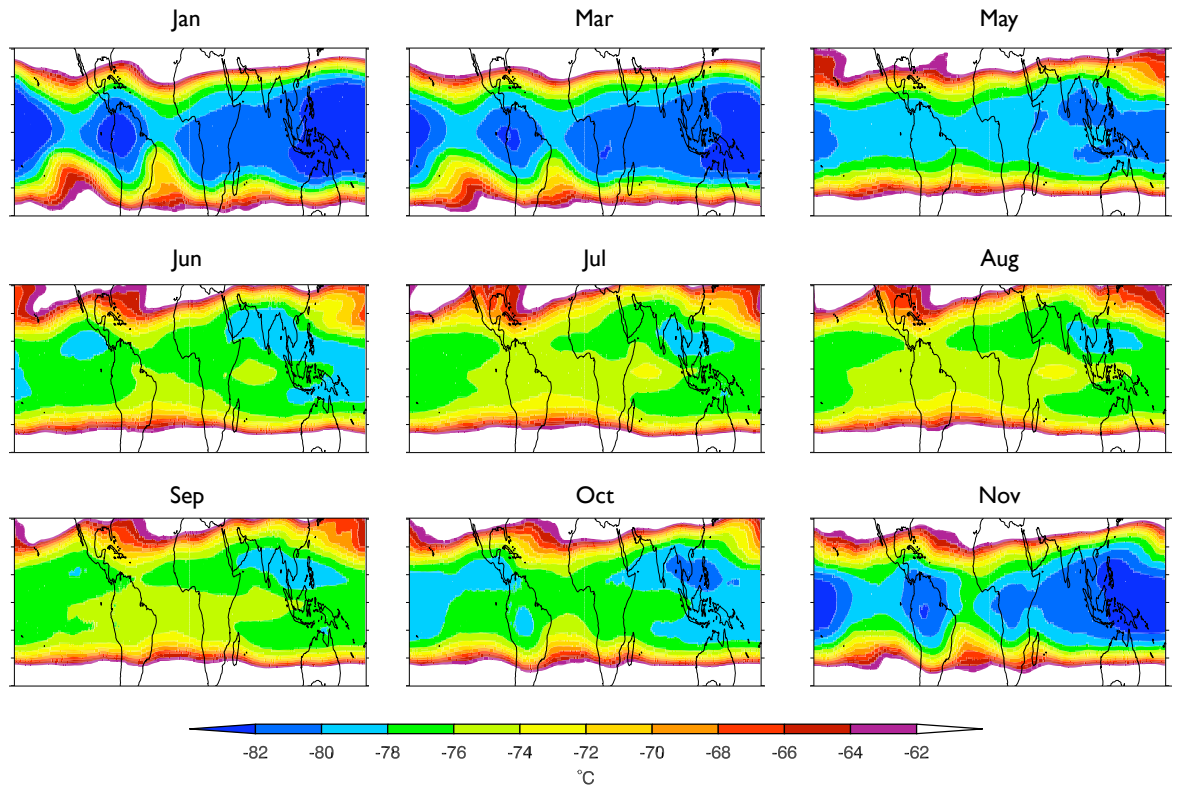

Figure 10: Monthly climatologies of blended tropopause temperature $\left({ }^{\circ} \mathrm{C}\right)$ in the tropics $\left( \pm 30^{\circ}\right)$ from the ERA-Interim climatology (1989-2007). 
In May, the tropical tropopause warms. A region of low temperature extends northwards over the Asian subcontinent from the west Pacific. By July the temperature minimum lies over the Bay of Bengal, with a region of low temperatures extending over the west Pacific. This is to the south-east of the height maximum, which is located over northern India. The temperature minimum remains over the Bay of Bengal until October, and returns to over the west Pacific in November. Tropical tropopause temperature decreases during this time. Local temperature minima range from $-86^{\circ} \mathrm{C}$ in January to $-79^{\circ} \mathrm{C}$ in August.

From November to April, tropopause height maxima and temperature minima are collocated (height is not shown, although see Figure 4 for seasonalmean values). However, when the region of high tropopause height extends northwards in May, there is a smaller northwest extension in the region of cold tropopause temperatures. The tropical tropopause warms in summer, as the height decreases, with a temperature minimum remaining over south-east Asia, to the south-east of the height maximum. Schmidt et al. (2004) found a similar tendency for colocation of maximum height and minimum temperature in DJF, but not in JJA. However, Seidel et al. (2001) found that the minimum thermal tropopause temperature only corresponded to the maximum height in $19 \%$ of cases in January.

The monthly means of tropopause parameters in the tropics all have clear annual cycles, although the amplitude is small compared to the high latitudes. Tropical average $\left( \pm 20^{\circ}\right.$ latitude) height has a minimum of $15900 \mathrm{~m}$ in July, and a maximum of $16400 \mathrm{~m}$ in April. Tropical mean temperature has a minimum $\left(-79.5^{\circ} \mathrm{C}\right)$ in January and a maximum $\left(-75.5^{\circ} \mathrm{C}\right)$ in August.

Area averages for the 'deep tropics' were also considered. This has been defined as the region equatorward of $10^{\circ}$ latitude, following IPCC (2007). Deep tropical height has a minimum of $16000 \mathrm{~m}$ in August, and a maximum of 16650 $\mathrm{m}$ in April. Temperature has the same annual cycle in the deep tropics as in the tropics, but the temperatures are colder, ranging from $-81.5^{\circ} \mathrm{C}$ in January to $-76.0^{\circ} \mathrm{C}$ in August. Seidel et al. (2001) identified a similar annual cycle in deep tropical height, with a minimum in July, and a maximum of $16800 \mathrm{~m}$ in April. The cycle found by Schmidt et al. (2004) for the same region has higher altitudes overall, with a smaller amplitude, ranging from $16800 \mathrm{~m}$ to $17000 \mathrm{~m}$. However, their evaluation is only based on a few years of data.

During El Niño, sea surface temperatures (SSTs) in the east Pacific Ocean increase and there is an associated increase in convection in the east and central Pacific, and a decrease in the west Pacific. Increased convection leads to a raised, cold, tropopause, and conversely for reduced convection. This can clearly be seen in the regression of DJFM mean tropopause pressure and temperature onto the DJFM mean Niño 3.4 SST index (found at www.cgd.ncar.edu/ cas/catalog/climind/TNI_N34/) shown in Figure 11. The raised tropopause in the western hemisphere, and the depressed tropopause signature in the eastern hemisphere are consistent with an enhanced Kelvin wave and a reduced Rossby wave respectively.

The patterns in the regression of pressure and temperature onto the Niño 


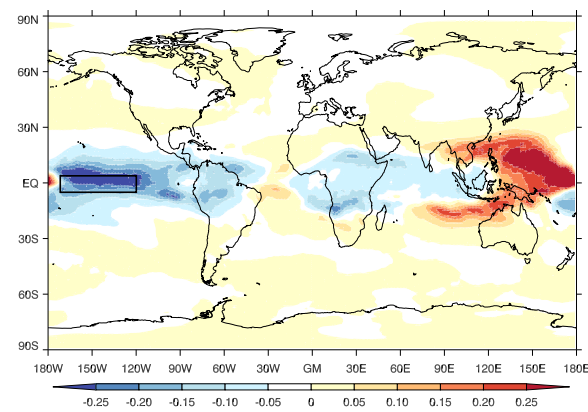

(a)

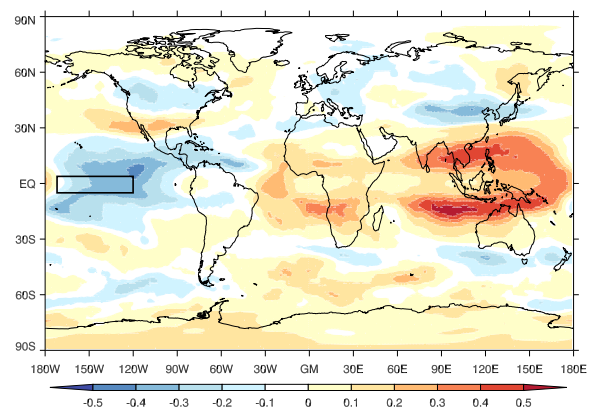

(b)

Figure 11: Regression of DJFM blended tropopause pressure [hPa] (a) and temperature $[\mathrm{K}](\mathrm{b})$ onto the Niño 3.4 SST index. The location of the Niño 3.4 region is indicated by the black boxes.

3.4 index, and their sign, differ over Africa. This structure was also identified by Zhou et al. (2001) in composites of the cold point tropopause from ERA-15 data for El Niño and La Niña, and by Randel et al. (2000) using radiosonde data.

The Pacific/North American pattern (PNA) is strongly influenced by ENSO. Positive PNA tends to occur in an ENSO event (e.g. Horel and Wallace, 1981) and is associated with a higher, colder tropopause over Hawaii and the northern US and Canada, and a lower warmer tropopause over the southern US. This is apparent in the regression of DJFM tropopause temperature onto the DJFM Niño 3.4 index (Figure 11(b)). It can also be detected in the regression of tropopause pressure onto the Niño 3.4 index, but the signal is weaker relative to the strong signals in the tropics.

\section{Summary}

A new global tropopause definition has been introduced that is based on flowdependent interpolation between the "dynamic" and thermal tropopause definitions. The advantages of such a flow-dependent definition are most clearly apparent on short timescales, in regions with synoptic-scale mixing between tropical and extratropical airmasses. It is the properties of the local airmasses that determine the boundary of the interpolation region, rather than an arbitrary latitudinal definition.

Climatologies of thermal, "dynamic", and blended tropopause height, and pressure, potential temperature, and zonal and meridional wind at the blended tropopause were produced for 1989-2007 using ERA-40 and ERA-Interim.

The blended tropopause is typically of order $100 \mathrm{~m}$ lower than the "dynamic" tropopause in the tropics in the zonal-mean climatology. However, it is still a significant modification to the "dynamic" tropopause as the difference between 
surfaces can be considerably larger than the climatological zonal-mean at a given time and location.

The use of the blended tropopause avoids the difficulties associated with using the thermal tropopause in the polar regions, and in the vicinity of strong jets. It reduces the reliance on the $380 \mathrm{~K}$ cap on the "dynamic" tropopause, although this issue is not completely resolved, with the cap being used over a small area in the subtropics in $<10 \%$ of 6 hourly cases.

Annual, seasonal and monthly climatologies have been produced using ERA40 and ERA-Interim and analysed globally, and for the high latitudes and tropics. Key features of the tropopause have been identified and found to be in agreement with previous studies.

In the $\mathrm{NH}$, tropopause height has a minimum over Canada and Greenland in the winter months, which moves over the pole in summer. Temperature has a minimum in the western hemisphere in winter, and maxima over the pole and near the position of the jet streams in summer. In the SH there is a height minimum and temperature maximum located on the Antarctic coast throughout the year. In Antarctic winter there is a strong temperature minimum over the pole. In the northern winter, the tropical tropopause is a fairly constant feature, with a temperature minimum over the Western Pacific. In the northern summer months the temperature of the tropical tropopause increases, and its structure is dominated by the Asian summer monsoon and its upper troposphere anticyclone. The regression of tropopause pressure and temperature onto the Niño 3.4 index reveals an ENSO signature of a Kelvin wave higher, colder tropopause to the east of the date line and a Rossby wave lower, warmer tropopause to the west.

Comparison of ERA-40 and ERA-Interim climatologies for the overlap period between the two reanalyses (1989-2002) has also been presented. It was found that the two tropopauses are generally within $300 \mathrm{~m}$ of each other. The largest difference was in the lee of the Himalayas in DJFM where the ERA-40 tropopause was up to $2 \mathrm{~km}$ higher than that from ERA-Interim. Generally there was more difference between the two tropopauses in the $\mathrm{SH}$ where there are fewer observations and the analysis is more susceptible to changes in the forecasting system. The ERA-40 tropical tropopause is warmer compared to ERA-Interim, with differences of up to $6^{\circ} \mathrm{C}$ over the central Pacific in JJA. Winds from the two reanalyses are generally within $2 \mathrm{~m} \mathrm{~s}^{-1}$, but JJA westerlies over the Indian ocean are up to $6 \mathrm{~m} \mathrm{~s}^{-1}$ stronger in ERA-40 compared to ERA-Interim.

\section{Acknowledgements}

This work was funded by the U.S. Federal Aviation Administration (FAA) under contract award DTRT57-07-P-80162. Any opinions, findings, and conclusions or recommendations expressed in this material are those of the authors and do not necessarily reflect the views of the research sponsor. We also acknowledge the use of ERA-Interim/40 data produced by ECMWF and provided by 
the British Atmospheric Data Centre and the National Centre for Atmospheric Science-Climate. The authors are grateful for the constructive comments of four anonymous reviewers.

\section{$7 \quad$ References}

Andersson E, Thépaut J-N. 2008. ECMWF's 4D-Var data assimilation system - the genesis and ten years in operations. ECMWF Newsletter 115: 8-12.

Danielsen EF. 1964. Project Springfield report. Washington D. C., Defense Atomic Support Agency Rept., DASA 1517, 97pp. (DDC).

Danielsen EF. 1968. Stratospheric-tropospheric exchange based on radioactivity, ozone and potential vorticity. J. Atmos. Sci. 25: 502-518.

Dee DP, Uppala SM, Simmons AJ, Berrisford P, Poli P, Kobayashi S, Andrae U, Balmaseda A, Balsamo G, Bauer P, Bechtold P, Beljaars ACM, van de Berg L, Bidlot J, Bormann N, Delsol C, Dragani R, Fuentes M, Geer AJ, Haimberger L, Healy SB, Hersbach H, Hólm EV, Isaksen L, Kållberg P, Köhler M, Matricardi M, McNally AP, Monge-Sanz BM, Morcrette J-J, Park B-K, Peubey C, de Rosnay P, Tavolate C, Thépaut J-N, Vitart F. 2011. The ERA-Interim reanalysis: configuration and performance of the data assimilation system. Q. J. R. Meteorol. Soc. 137: 553-597.

Duncan BN, Strahan SE, Yoshida Y, Steenrod SD, Livesey N. 2007. Model study of the cross-tropopause transport of biomass burning pollution. Atmos. Chem. Phys. 7: 3713-3736.

Forster C, Stohl A, James P, Thouret V. 2003. The residence times of aircraft emissions in the stratosphere using a mean emission inventory and emissions along actual flight tracks. J. Geophys. Res. 108 D12: 8524. DOI:10.1029/2002JD002515.

Gettelman A, and Baughcum SL. 1999. Direct deposition of subsonic emissions into the stratosphere. J. Geophys. Res. 104: 8317-8327.

Hagemann S, Arpe K, Bengtsson L. 2005. Validation of the hydrological cycle in ERA-40. ERA-40 Project Report Series, 24.

Highwood EJ, Hoskins BJ. 1998. The tropical tropopause. Q. J. R. Meteorol. Soc.. 124(549): 1579-1604. DOI:10.1002/qj.49712454911.

Highwood EJ, Hoskins BJ, Berrisford P. 2000. Properties of the arctic tropopause. Q. J. R. Meteorol. Soc. 126(565): 1515-1532. DOI:10.1002/qj.49712656515.

Hoerling MP, Schaack TK, Lenzen AJ. 1991. Global objective tropopause analysis. Mon. Weather Rev. 119: 1816-1831. 
Hoinka KP. 1998. Statistics of the global tropopause pressure. Mon. Weather Rev. 126: 3303-3325.

Hoinka KP. 1999. Temperature, humidity, and wind at the global tropopause. Mon. Weather Rev. 127: 2248-2265.

Holton JR, Haynes PH, McIntyre ME, Douglass AR, Rood RB, Pfister L. 1995. Stratosphere-troposphere exchange. Rev. Geophys., 33: 403-439. DOI:10.1029/9512G02097.

Horel JD, Wallace JM. 1981. Planetary-scale atmospheric phenomena associated with the Southern Oscillation. Mon. Weather Rev. 109: 813-829.

Hoskins BJ, McIntyre ME, Robertson WA. 1985. On the use and significance of isentropic potential vorticity maps. Q. J. R. Meteorol. Soc. 111 (470): 877-946.

IPCC: Climate Change 2007: The physical science basis. Contribution of working group I to the Fourth Assessment Report of the Intergovernmental Panel on Climate Change, edited by: Solomon s, Qin D, Manning M, marquis M, Averyt K, Tignor MMB, Miller HL, Chen Z. Cambridge University Press, Cambridge, UK, 996pp.

Kunz A, Konopka P, Müller R, Pan LL. 2011. Dynamical tropopause based on isentropic potential vorticity gradients. J. Geophys. Res. 116: D01110.

Juckes M. 1994. Quasigeostrophic dynamics of the tropopause. J. Atmos. Sci. 51(19): 2756-2768

Randel WJ, Wu F, Gaffen DJ. 2000. Interannual variability of the tropical tropopause derived from radiosonde data and NCEP reanalyses. J. Geophys. Res. 105(D12): 15509-15524. DOI:10.1029/2000JD900155

Randel WJ, Wu F, Oltmas SJ, Rosenlof K, Nedoluha GE. 2004. Interannual changes of stratospheric water vapor and correlations with tropical tropopause temperatures. J. Atmos. Sci. 61: 2133-2148.

Reichler T, Dameris M, Sausen R. 2003. Determining the tropopause height from gridded data. Geophys. Res. Lett. 30: 2042.

Santer BD, Wigley TML, Simmons AJ, Kållberg PW, Kelly GA, Uppala SM, Ammann C, Boyle JS, Brüggemann W, Doutriaux C, Fiorino M, Mears C, Meehl GA, Sausen R, Taylor KE, Washington WM, Wehner MF, Wentz FJ. 2004. Identification of anthropogenic climate change using a second-generation reanalysis. J. Geophys. Res. 109: D21104. doi: 10.1029/2004JD005075.

Schmidt T, Wickert J, Beyerle G, and Reigber C. 2004. Tropical tropopause parameters derived from GPS radio occultation measurements with CHAMP. J. Geophys. Res. 109: D13105, doi:10.1029/2004JD004566 
Schmidt T, Heise S, Wickert J, Beyerle G, and Reigber C. 2005. GPS radio occultation with CHAMP and SAC-C: global monitoring of thermal tropopause parameters. Atmos. Chem. Phys. 5: 1473-1488.

Seidel DJ, Ross RJ, Angell JK, and Reid GC. 2001. Climatological characteristics of the tropical tropopause as revealed by radiosondes. J. Geophys. Res. 106: 7875-7878.

Shapiro MA. 1978. Further evidence of the mesoscale and turbulent structure of upper level jet stream-frontal zone systems. Mon. Weather Rev. 106: $1100-1111$.

Shapiro MA. 1980. Turbulent mixing within tropopause folds as a mechanism for the exchange of chemical constituents between the troposphere and stratosphere. J. Atmos. Sci. 37: 994-1004.

Simmons AJ, Uppala S, Dee D, Kobayashi S. 2007. ERA-Interim: New ECMWF reanalysis products from 1989 onwards. ECMWF Newsletter 110: $25-35$.

Uppala SM, Kållberg PW, Simmons AJ, Andrae U, Da Costa Bechtold V, Fiorino M, Gibson JK, Haseler J, Hernandez A, Kelly GA, Li X, Onogi K, Saarinen S, Sokka N, Allan RP, Andersson E, Arpe K, Balmaseda MA, Beljaars ACM, Van De Berg L, Bidlot J, Bormann N, Caires S, Chevallier F, Dethof A, Dragosavae M, Fisher M, Fuentes M, Hagemann A, Hólm E, Hoskins BJ, Isaksen L, Janssen PAEM, Jenne R, Mcnally AP, Mahfouf JF, Morcrette J-J, Rayner NA, Saunders RW, Simon P, Sterl A, Trenberth KE, Untch A, Vasiljevie D, Viterbo P, Woollen, J. 2005. The ERA-40 reanalysis, Q. J. R. Meteorol. Soc. 131: 2961-3012. DOI: 10.1256/qj.04.174

Vaughan G, Price JD. 1991. On the relation between total ozone and meteorology. Q. J. R. Meteorol. Soc. 117: 1281-1298. DOI:10.1002/qj.49711750208.

Wilcox LJ, Hoskins BJ, Shine KP. 2011. A global blended tropopause based on ERA data. Part II: Trends and tropical broadening. Q. J. R. Meteorol. Soc., accepted.

Wirth, V. 2000. Thermal versus dynamical tropopause in upper-tropospheric balanced flow anomalies. Q. J. R. Meteorol. Soc. 126: 299-317.

Wirth, V. 2001. Cyclone-anticyclone asymmetry concerning the height of the thermal and the dynamical tropopause. J. Atmos. Sci 58: 26-37.

World Meteorological Organization. 1957. Meteorology - a three-dimensional science. WMO Bull. 6: 134-138.

Zängl G, Hoinka KP. 2001. The tropopause in the polar regions. J. Climate 14(14): 3117-3139. 
Zhou XL, Geller MA, and Zhang MH. 2001. Tropical Cold Point Tropopause Characteristics Derived from ECMWF Reanalyses and Soundings. J. Climate 14: 1823-1838. 